\title{
Impact of Entrepreneurial Orientation and Network Resource Utilization on Internationalization of SME's: Evidence from Pakistan
}

\author{
Muhammad Imran Hanif ${ }^{1} \&$ Madiha Irshad ${ }^{1}$ \\ ${ }^{1}$ Institute of Banking and Finance, Bahauddin Zakariya University Multan, Pakistan \\ Correspondence: Muhammad Imran Hanif, Institute of Banking and Finance, Bahauddin Zakariya University \\ Multan, Pakistan.
}

Received: February 13, 2018

Accepted: April 2, 2018 Online Published: May 15, 2018

doi:10.5539/ijms.v10n2p118

URL: https://doi.org/10.5539/ijms.v10n2p118

\begin{abstract}
The purpose of this study is to examine the importance of implementation of strong entrepreneurial orientation and utilization of network resources creating value added products for the internationalization of Small and Medium Enterprises in Pakistan. The objective is to investigate and evaluate the nature of the business, then to determine the importance of implementation of entrepreneurial orientation and utilization of network resources for the internationalization of small and medium sized enterprises in Pakistan. It is proposed that the intensity of internationalization of small and medium sized enterprises is enhanced by development of organizational practices and cultural environment. An overview is provided of the importance of SME sector in Pakistan for the economic growth of the country. The current state of SME sector has been evaluated. It proceeds with the discussion of the factors essential for fostering the growth of SME's in Pakistan. The importance of these factors such as strong entrepreneurial orientation and utilization of network resources has also been considered for the internationalization of small and medium sized enterprises in Pakistan.

The paper concludes with the assessments of implications of these factors and suggestions for future research. Information is provided regarding the current situation of SME's in Pakistan and the factors for the international growth of this sector have also been identified and studied. Factors under consideration are strong entrepreneurial orientation and utilization of network resources. Few hypotheses made regarding the implication of these factors have been evaluated and tested by several statistical methods. For the internationalization of SME's in Pakistan these factors have been given special attention. In the industrial development of a country the importance of the SME sector cannot be ignored. SMEs constitute nearly $90 \%$ of all the enterprises in Pakistan; employ $80 \%$ of the non-agricultural labor force; and their share in the annual GDP is $40 \%$, approximately. However, Pakistan Small and Medium Enterprises sector is facing many problems and challenges both domestic and international in achieving economics of scale and better prospects in marketing their products at international market and to gain the competitive advantage. Demand of the global era requires entrepreneurs who are willing to face risks, innovative, proactive and compete aggressively to be able to seek new opportunities and increase competition advantages. Innovation is needed to provide value added products through value creation, so that the competitive advantage could be gained. Entrepreneurs can utilize open source that involves external parties by utilizing network resources. This paper calls attention to ways in which SME's of Pakistan can survive in this competitive environment. This paper investigates the chief factors for the internationalization of SME's of Pakistan specifically focusing on the entrepreneurial orientation determinants such as pro-activeness, risk taking and competitive aggressiveness and utilization of network resources.
\end{abstract}

Keywords: entrepreneurial orientation, network resources utilization, internationalization, small and medium sized enterprises, Pakistan, pro-activeness, risk taking, competitive aggressiveness

\section{Introduction}

Internationalization is an ambiguous term which is defined slightly differently in multiple studies. Internationalization is an adaptation of a firm's operations including its structure, strategy and resources etc. to international environments (Calof \& Beamish, 1995). Companies doing internationalization get the benefit of cost advantage, network benefit and learning opportunities (Verdin \& Heck, 2001). Internationalization is further defined as process to approach foreign markets and then making efforts to get a prominent position within different networks (Schweizer et al., 2010). 
Four modes of internationalization are different from each other where latter represents higher degrees of international involvement i.e., no regular export activities, export via independent representatives (agents), establishment of an overseas sales subsidiary and overseas production/manufacturing units (Johanson et al., 1975).

The internationalization process of small and medium sized firms has been subjected to widespread empirical research (Cavusgil et al., 2012; Dichtl et al., 1984), and seems to be beneficial by a general acceptance in the literature (Reid \& Rosson 1987; Welch \& Luostarinen, 1988; cf. Bradley, 1991). In recent years SME's are entering in international markets and expanding their business by establishing their strategies on the basis of international diversification to enhance their performance (Masum \& Fernandez, 2008).

With the liberalization of trade and technological advancements, there have emerged new challenges as well as new competitions in both local and international markets. Despite the presence of large organizations with their technological advancements, SMEs continue to play their vital role in the national economic development (Hussain, Kamariah Ismail, \& Akhtar, 2015). Doing business in international market for SMEs is a hard challenge. It is not an easy challenge because they have to prepare themselves for a tough competition with other business actors in international market (Ginting, 2015). In Pakistan SME sector is less formally organized as compared to many developing countries and the economic environment also hinders competitive growth of the sector (FBS, 2011; Mirani \& Shah, 2012).

In Pakistan, SME's operating in tough international competitive environment need much attention on their internal capabilities to enhance their performance (Ahmad et al., 2013; FBS, 2011; Mustafa \& Khan, 2005). Hence there is always a gap for further improvement in SME's of Pakistan and intensive research is needed to be done by scholars and entrepreneurs to fill this gap so that the economy can grow by improved business activities (Jasra et al., 2011).

This study is made to highlight the significance of strong entrepreneurial orientation for the development of SME's. This study aims to demonstrate that if SME's desire to enter the international market then the empowerment of entrepreneurial orientation in SME sector can support this purpose. The purpose of this study is to prove the co-innovation as better strategy to get the competitive advantage and this can help in the development of SME sector not only on the local level but also at the international level. Another significance of this paper is to prove the importance of utilization of network resources policy to make a strong position in the market and to internationalize the business for SME's.

This paper is structured as follows. In the next section, theoretical framework is presented by which empirical hypotheses are developed which we are proposed to test. The third section demonstrates the data set and the statistical approach used. The fourth section describes the results of the analysis and provides the discussion of the results. The final section offers some conclusions, managerial implications, limitations and areas for future research.

\section{Literature Review and Theoretical Framework}

Due to global economic integration the competitive environment has been changed in which all businesses operate and it requires them to adapt an international expansion strategy to positively affect their long term growth and survival (Karagozoglou \& Lindell, 1998). Similarly, due the phenomenon of globalization firms are increasingly going for international activities as competition has also been increased (Bartlett \& Ghoshal, 2000). Because of increasing and major contribution of SME's in economic development and employment availability there is a need to study the factors affecting the internationalization of SME's. This sector cannot be ignored as they are also going to internationalize their business for their survival. In the following lines, we try to develop these ideas and some hypotheses related to them.

\subsection{Dimensions of Entrepreneurial Orientation}

Firm's organizational processes and strategies when acting entrepreneurially can be described by using the labels such as entrepreneurship and entrepreneurial orientation (Miller, 1983; Lumpkin \& Dess, 1996).

An entrepreneurial firm undertakes product market innovation, risky ventures, quickly come with proactive innovations and beat competitors to punch. So, innovativeness, risk taking and pro-activeness are the dimensions of entrepreneurial orientation to test entrepreneurship (Miller, 1983). It is later supported that entrepreneurial orientation is composed of firm's risk-taking propensity, proactive manners and extensive product innovation (Slevin \& Covin, 1990).

Competitive aggressiveness is also a crucial dimension of entrepreneurial orientation as SME's also need to compete with their existing rivals (Miller, 1983). Competitive aggressiveness is highly correlated with 
entrepreneurship of an entrepreneurial firm in all levels of risk either low or high risk environments (Dean et al., 1998).

This study is focusing on three dimensions of entrepreneurial orientation i.e., risk taking, pro-activeness and competitive aggressiveness.

\subsubsection{Risk Taking}

The early literature equates entrepreneurship with finding self-employment instead of working for others for the sake of wages (Shane, 1994). It is consistent with the concept that the major factor which separates entrepreneurs from hired personnel is uncertainty and riskiness of self-employment. So, risk taking is a quality of entrepreneurship (McMullent et al., 2006).

Many researchers have found out that entrepreneurial firms not always use risk-taking behavior (Brockhaus, 1982). Entrepreneurial firms equate risk taking with performance (Begley \& Boyd, 1987). Entrepreneurial firms measure risk taking at firm level by analyzing the performance of risky projects and use to ask managers about their views regarding being risky or cautious to gain firm objectives (Venkatraman, 1989).

Further, risk taking has been defined as a characteristic of entrepreneurial firms that helps in the management of firm's risks and support SME's to take risk in their operations (Fletcher, 2004).

\subsubsection{Pro-activeness}

The term pro-activeness is foreseeing future problems, needs or changes and then acting according by developing proactive strategies (Webster, 1992). Pro-activeness is very important for entrepreneurial orientation as it helps in the development of innovative strategies to cope up with future demands. Pro-activeness of an entrepreneurial firm is to shape the environment rather than merely react (Miller \& Friesen, 1978).

Later, pro-activeness was defined to depict a firm first to introduce new products or services and quick to innovate. Entrepreneurial firm is first to come up with proactive innovations (Miller, 1983). The concept to act by foreseeing a future demand is crucial component of entrepreneurship. An entrepreneurial firm should come up with forward thinking and it's not compulsory for an entrepreneurial firm to being always first to market. A firm can achieve equal success by being second to market through pro-activeness (Miller \& Camp, 1986).

In contrast, first-mover advantage is the best strategy to avail market opportunity. First movers get more and unusual benefits and high profits as well as prominent brand recognition in entrepreneurship literature (Lieberman \& Montgomery, 1988).

\subsubsection{Competitive Aggressiveness}

New entrepreneurial firms face more danger of newness and it is very essential for them to develop legal and strong strategies regarding their suppliers, customers and competitors for their survival (Stinchcombe, 1965). Because new ventures face failure much faster than established businesses and it has been investigated that increasing competition is very dangerous for their survival and existence (MacMillan, 1987; Porter, 1985).

A new entrepreneurial firm can survive in a highly competitive environment by employing three approaches. First one is reconfiguration that is performing things differently. Second one is changing the context which is making the products and services innovative. Third one is changing the market channels or scope that is outspending industry leader (Porter, 1985).

Hence, competitive aggressiveness is to gain competitive advantage and is analyzed to be an important dimension of entrepreneurial orientation. It highlights the importance of competitive advantage for the survival of an entrepreneurial firm in a very competitive environment (Dean, 1998).

\subsection{Entrepreneurial Orientation and Internationalization Relationship}

Innovativeness, pro-activeness and risk taking behavior combine to explain international entrepreneurship. These dimensions enable to internationalize their business by creating value in the entrepreneurial firms (McDougall \& Oviatt, 2000). Behavioral characteristics of managers of an entrepreneurial firm specifically the dimensions of risk taking, pro-activeness and innovativeness are the main focus of international entrepreneurship (Knight, 2001).

Later on it was found that entrepreneurship plays an important role in the internationalization of SME's and this is explained by a theory called "International Entrepreneurship Theory (IET)" (McDougall \& Oviatt, 2000).

International Entrepreneurship theory says that innovative, proactive and risk seeking behavior combine to explain international entrepreneurship which help the organizations to cross the borders and increase their performance and value (McDougall \& Oviatt, 2000). It is further supported that the organizations get the primary 
benefit of increase in performance by fast internationalization (Autio, Sapienza, \& Almeida, 2000).

As the internationalization opportunities are increased due to entrepreneurship so it implies that all entrepreneurial activities possess potential of international dimension. Propensity to take risk is a prominent dimension of entrepreneurial orientation and risks in international projects can be managed and reduced by carefully analyzing this dimension (Fletcher, 2004).

Increasing demand of international brands and services clearly depicts the rapid expansion of businesses to international markets (Javalgi \& Ramsey, 2001). Because of this increasing expansion of businesses to international markets small and medium enterprises are facing a great pressure of competitors to internationalize their business for their survival and growth. Competitive aggressiveness needs to be adapted to get the competitive advantage over competitors in international market (Patricia \& Javalgi, 2011).

Small and medium sized enterprises having strong entrepreneurial orientation are more likely to go for internationalization of their business as strong entrepreneurial orientation encourages in making strong international strategies (Lan \& $\mathrm{Wu}, 2010)$.

There is a very close relationship between entrepreneurship and internationalization of SME's (Clerg et al., 2005; Melia et al., 2007; Lan \& Wu, 2010). Similar to this context, for getting international market entrepreneurial orientation can be utilized in terms of proactiveness and competitive aggressiveness as well as risk taking (Okpara, 2009).

By analyzing international entrepreneurship from entrepreneurship perspective it has become clear that there are entrepreneurial dimensions that increase the speed of entrepreneurial firms to operate simultaneously in different countries (Zahra \& Gravis, 2000; Realp et al., 2005; Casillads et al., 2009).

It is further explained that the firms having employees with strong entrepreneurial orientation like having characteristics of taking risks, adapting innovation, having showing competitive aggressiveness, being proactive in market place and ability to take autonomous actions lead the firms more successfully and increase the speed of growth and improve performance of a firm (Chen et al., 2011).

It is further stated that due to high competition level in international business SME's need business actors with high entrepreneurial orientation (Ginta Ginting, 2015). So, it can be stated that SME's having objective to approach international market and global success first need to focus on developing capabilities to withstand global competitive pressure, focus on improving industry characteristics and then improve competitive capabilities (Sebnem \& Melisa., 2014). So by looking at this literature we can develop a hypothesis:

H1: Stronger the entrepreneurial orientation support, Stronger the intensity of doing international activities.

\subsection{Network Resources Utilization and Internationalization Relationship}

For an entrepreneurial firm networking is very powerful tool for its growth (Dubini \& Aldrich, 1999). For internationalization of an entrepreneurial firm network analysis has been studied by many researchers (Bell, 1995; Covoello \& Munro, 2000; Oviatt \& McDougall, 1994).

Further it is stated that better explanation of internationalization of entrepreneurial firms is understood by analyzing its network approach (Bell, 1995). In studying the network approach of SME's towards internationalization different researchers came up with different theories and models.

Johanson \& Wiedersheim-Paul (1975) presented an Uppsala Internationalization Process Model in which they differentiated the four stages of internationalization process. This is an incremental stage model. Each successive stage shows higher degrees of international involvement with the increasing utilization of network resources and knowledge.

Referring to internationalization of SME's it is not always necessary that companies follow the linear path of Uppsala model for the internationalization of their business regarding resource commitments, knowledge and investments. Regarding internationalization of SME's there are three aspects. At first, SME's may internationalize due to their relationships with their customers which help them to the selection of their entry mode in the foreign market.

Secondly internationalization also occurs due to their relationships established with their clients, suppliers and even with their competitors. Thirdly, internationalization also occurs due to the already established relationship networks which effect their operations and facilitate them in providing direction to enter the international market and compete with their competitors (Buckley \& Ghauri, 1999).

Further (Johanson \& Mattsson, 1988; Anderson, 1993) did work on internationalization and come up with 
another model known as "The Network Approach Model".

Johanson and Mattsson introduced a model regarding internationalization of firms known as "The Network Approach Model". In this model they described that in order to go abroad it is very important for firms to have strong and faithful relationships with their suppliers, customers and market. This relationship not only helps the firms to expand internationally but also increase their growth and performance (Johanson \& Mattsson, 1988).

This model was supported by Anderson in 1993. Anderson came up with a very minor change in this model by highlighting the importance of timing. In order to know that how much the interdependence is coordinated between partly and imperfectly pre- planned sequences of two actors it is very important to understand the timing of strategic action (Anderson, 1993). More work is done on this network approach such as (Hakansson \& Snehota, 1995; Wacker, 1998; Adelegan et al., 2008; Johanson et al., 2012; Ford \& Mouzas, 2013)

International New Venture (INV) theory explains the internationalization of SME's. INV theory says that INVs internationalize by seeking the opportunities and gaining the competitive advantage from the use of resources and sale of products in multiple countries (Oviatt \& McDougall, 1994).

Similarly high density of external networks results in successful internationalization of entrepreneurial firms. Already established networks help in a rapid internationalization of a firm (Benjamin et al., 2005). It is further found that limited utilization of network resources result in worst international as well as national performance of small and medium sized firms (Cerrato \& Piva, 2008).

Recent studies have shown that firms have started to put emphasis on the utilization of external and internal network resources for the recognition of international opportunities and bring innovation in their products and services for meeting the challenges of competitors in this globalized world (Johanson \& Vahlne, 2006).

However, network building is not an easy task for small and medium sized enterprises. To survive in this globalized world open sourcing is the best strategy to bring co-innovation and open innovation through the collaboration of other parties in the network (Odentahal, 2004). It has also been observed that those SME's not going to internalization of their business lack utilization of their network resources (Abdullah \& Zain, 2011).

Hence, network building not only involves the utilization of current networks but also involves the connections with external network sources by making trustworthy contacts with the firms working in foreign markets. These will strong their network as well as provide support for entering in international markets (Mujdelen et al., 2014).

It is further supported that for the internalization of small and medium enterprises external sources should be considered in network formation (Sebnem \& Melisa, 2014). So, by taking a careful view on the above literature it can be hypothesized that:

H2: Stronger the network resources utilization, Stronger the intensity of doing international activities of SME's.

Hypothesized Research model developed for this paper is as follows:

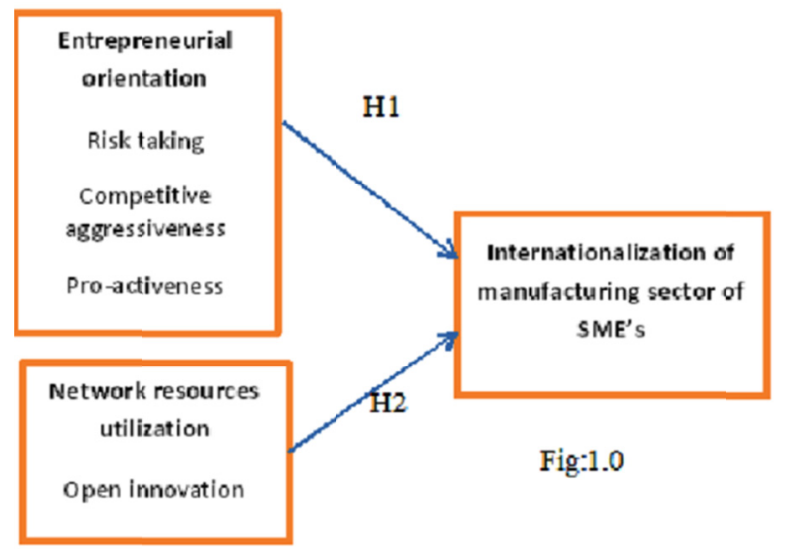

Figure 1. Hypothesized model 


\section{Methodology}

\subsection{Data and Sample}

For addressing the problem being studied in this paper a proper research plan is designed. This is a descriptive type study in which a systemized questionnaire is designed. Questionnaire includes closed ended questions regarding each variable of this study. Further survey methodology is used by visiting SME's of Pakistan. It is a quantitative research in which the data collected is statistically analyzed and conclusion drawn is in percentages or figures to select or reject the hypotheses of this study.

Survey was conducted in 200 SME's of 4 cities of Pakistan that are Lahore, Islamabad, Karachi and Multan. The sample comprised of 250 top managers of 200 SME's. In the beginning questionnaires were sent through email, but because of low response of questionnaire filling through email and Skype interviews were conducted and personal visits are also conducted. But as most SME's comprise of just two or three top managers because of their small size and also due to non- availability of top managers because of busy schedule the respondents' size became 200.

Respondents of this study are selected demographically on the basis of age, education and position of respondent in a firm. These factors are taken into account because they contribute in assessing their experience towards business approach as well as their knowledge about market place as more experience brings more knowledge and creation of many advanced attributes that play an important role in performance of firms as this research is being conducted from to managers of SME's. Top management is a key in development of strategies of a firm regarding each department. SME's segmentation is done on the basis of its characteristics including its age, type of ownership and its number of employees.

\subsection{Variables and Measures}

\subsubsection{Entrepreneurial Orientation}

Entrepreneurial orientation is taken as an independent variable in this paper. It is measured by studying pro-activeness (Miller \& Friesen, 1978), risk taking (Venkatraman, 1989) and competitive aggressiveness (Dean, 1998 ) as three of its dimensions (Covin \& Slevin, 1989). We use subjective measurement of entrepreneurial orientation as it has also been used by several other authors (Stanley, 2012). To measure entrepreneurial orientation of small and medium sized enterprises top managers were asked several closed ended questions regarding their actions towards market competitive environment.

\subsubsection{Utilization of Network Resources}

Network resources utilization is taken as a second independent variable in this paper. It is measured by taking open innovation/co-innovation utilizing external and internal sources for adding value to products and services (Michael Fritsch, 2001).

\subsubsection{Internationalization Intensity}

Internationalization intensity is taken as a dependent variable in this paper. We have used subjective measurement of internationalization intensity by taking firms internationalization speed and profit intensity into consideration (Daniel Sullivan, 1994).

After collection of data through questionnaire it is analyzed by entering data in SPSS. SPSS software is used to summarize and analysis of data. Through SPSS statistical analysis is done to prove the hypotheses. Reliability of data is analyzed by applying reliability statistics. Cronbach's alpha is used to show the reliability of items of questionnaire regarding variables. Because for the reliability of data Chronbach's alpha can be used (Shiken, 2011). Values of alpha higher than 0 are more reliable while negative values less than 0 are not reliable. Cronbach's alpha threshold is 0.7 . Values greater than 0.7 are more reliable.

To test the adequacy of sampling data KMO and Bartlett's test is used. Threshold value of this test is 0.5 and the values greater than 0.5 show more accuracy of data. Similarly, Bertlrtt's test of sphericity is used to test the validity and suitability of the responses collected to solve the problem being addressed. The value of this test should be less than 0.05. Both KMO and Bartlett's test of Sphericity are used to test the adequacy of sample.

Five-point likert scale is used for the measurement of variables. Descriptive statistics is used to summarize the sample demographic measures showing the mean and standard deviation values of each measure. Furthermore, correlational analysis is done to show the extent of relationship between variables of study. Descriptive statistics and coorelation can be used for the statistical analysis of data with Likert scale (Shiken, 2011). Furthermore, parametric statistics can be used with likert data with no fear of coming to wrong conclusion (Geoff Norman, 2010). 
Further, after correlation is tested regression analysis approach is used to test the hypotheses. In simple regression analysis, model summary shows the " $R$ " and " $R$ square" values. "R" values represent the simple correlation while " $R$ square" value represents the total variation in dependent variable. After computation of variation ANOVA is computed. ANOVA represents significance of dependent variable by keeping the independent variable constant. For $p>0.05$ then the results are significant. In coefficient table standardized regression beta values which is a measure of strength of relationship between two variables. Further for the measurement of mediation of internationalization multiple regression analysis is used.

\section{Results}

This section discusses the results obtained after analysis of data. This section will tell us that either the hypotheses developed in this research are accepted or rejected after analysis of obtained data by applying several statistical tests using certain a statistical data analysis software SPSS. Results obtained are given below with their interpretation.

\subsection{Reliability Statistics}

The table of Reliability statistics shows the alpha values of the questionnaire items which were 22 is 0.915 .which is more than the threshold alpha value 0.7

Table 1. Reliability statistics

\begin{tabular}{ll}
\hline Chronbach's Alpha & No. of items \\
\hline 0.915 & 22 \\
\hline
\end{tabular}

\subsection{KMO and Bartlett's Test}

The table of Kaiser-Meyer-Olkin (KMO) and Bartlett's test of sphericity is conducted to check the sample adequacy of the data. The value of KMO is 0.856 which is more than the KMO threshold which is 0.5

Table 2. KMO and Bartlett's test

\begin{tabular}{lll}
\hline Kaiser-Meyer-Olkin Measure of Sampling Adequacy. & & $\mathbf{. 8 5 6}$ \\
\hline Bartlett's Test of Sphericity & Approx. Chi-Square & 3270.563 \\
& Df & 378 \\
& Sig. & .000 \\
\hline
\end{tabular}

\subsection{Demographic Profile}

Following are the demographic profile of the respondents

\subsubsection{Age of Respondents}

The table showed the ages of respondents. Majority of respondents were between the age group of 30-39. They were 87 , while 48 respondents were between 40 to 49 age group and 65 respondents were lies in the first age group.

Table 3. Age

\begin{tabular}{llllll}
\hline & & Frequency & Percent & Valid Percent & Cumulative Percent \\
\hline Valid & $20-29$ & 65 & 32.5 & 32.5 & 32.5 \\
& $30-39$ & 87 & 43.5 & 43.5 & 76.0 \\
& $40-49$ & 48 & 24.0 & 24.0 & 100.0 \\
& Total & $\mathbf{2 0 0}$ & $\mathbf{1 0 0 . 0}$ & $\mathbf{1 0 0 . 0}$ & \\
\hline
\end{tabular}

\subsubsection{Education of Respondents}

According to below table, there are different frequencies and percentages at different levels. At level BA/BSC there were $21 \%$ respondents, $72 \%$ have the master's degree. And only $7 \%$ respondents were M.phil or having MS degree. 
Table 4. Education

\begin{tabular}{llllll}
\hline & & Frequency & Percent & Valid Percent & Cumulative Percent \\
\hline Valid & BA/BSC & 42 & 21.0 & 21.0 & 21.0 \\
& BS/MA/MSC & 144 & 72.0 & 72.0 & 93.0 \\
& MS/M.Phil & 14 & 7.0 & 7.0 & 100.0 \\
& Total & $\mathbf{2 0 0}$ & $\mathbf{1 0 0 . 0}$ & $\mathbf{1 0 0 . 0}$ & \\
\hline
\end{tabular}

\subsubsection{Current Experience of Respondents}

The table shows the current experience of respondents. More than $23.5 \%$ were the founder and owners of SME's. $48 \%$ respondents were the owner and $28.5 \%$ of respondents were only manger over there.

Table 5. Current experience

\begin{tabular}{|c|c|c|c|c|c|}
\hline & & Frequency & Percent & Valid Percent & Cumulative Percent \\
\hline \multirow[t]{4}{*}{ Valid } & Founder and Owner & 47 & 23.5 & 23.5 & 23.5 \\
\hline & Owner & 96 & 48.0 & 48.0 & 71.5 \\
\hline & Manager & 57 & 28.5 & 28.5 & 100.0 \\
\hline & Total & 200 & 100.0 & 100.0 & \\
\hline
\end{tabular}

\subsubsection{Total Number of Employees}

According to this table, in the range of 10-20 number of employees there were $29.5 \%$ respondents, range of 21-40 number of employees there were 50.5\%, but at $41-50$ there were $18.8 \%$ have 21 to 40 employees, only 51 to 60 there were $1.5 \%$ number of employees.

Table 6. Total employees

\begin{tabular}{llllll}
\hline & & Frequency & Percent & Valid Percent & Cumulative Percent \\
\hline Valid & 10_20 & 59 & 29.5 & 29.5 & 29.5 \\
& $21 \_40$ & 101 & 50.5 & 50.5 & 80.0 \\
& $41 \_50$ & 37 & 18.5 & 18.5 & 98.5 \\
& 51_60 & 3 & 1.5 & 1.5 & 100.0 \\
& Total & $\mathbf{2 0 0}$ & $\mathbf{1 0 0 . 0}$ & $\mathbf{1 0 0 . 0}$ & \\
\hline
\end{tabular}

\subsection{Descriptive Analysis}

This table presents the descriptive statistics. Total 200 respondents were recorded for this study. It indicated that, majority of respondents age group existed between 40 to 49 years. For education mean value shows that majority of respondents are masters and bachelors. Current experience of respondents shows that (2.0) maximum respondents are owners. Majority of number of employees under working respondents are 10 to 40.

Table 7. Descriptive statistics

\begin{tabular}{llllll}
\hline & N & Minimum & Maximum & Mean & Std. Deviation \\
\hline Age & 200 & 1.00 & 3.00 & 1.9150 & .74872 \\
Education & 200 & 1.00 & 3.00 & 1.8600 & .51157 \\
Cur_Exp & 200 & 1.00 & 3.00 & 2.0500 & .72118 \\
Total_Emp & 200 & 1.00 & 4.00 & 1.9200 & .73231 \\
Valid N (listwise) & 200 & & & & \\
\hline
\end{tabular}

\subsection{Correlations Analysis}

Table 8. Correlations analysis

\begin{tabular}{|c|c|c|c|}
\hline & Ent_Orientation & Network_Resources & Int_Intensity \\
\hline Ent_Orientation & 1 & & \\
\hline Network_Resources & $.766^{* *}$ & 1 & \\
\hline Int Intensity & $.580^{* *}$ & $.543^{* *}$ & 1 \\
\hline
\end{tabular}


In the correlation matrix all the variables have positive relationship. The table shows the correlation between the construct this table matrix shows the entire hypothesis having relationship with each other. The results of hypothesis one shows the 0.580 correlation. Hypothesis two shows the 0.543 correlation.

\subsection{Regression Analysis}

Table 9. Model summary

\begin{tabular}{lllll}
\hline Model & $\mathbf{R}$ & R Square & Adjusted R Square & Std. Error of the Estimate \\
\hline $\mathbf{1}$ & $.580^{\mathrm{a}}$ & .336 & .333 & .742 \\
a. Predictors: (Constant), Ent_Orientation & \\
\hline
\end{tabular}

Table 10. NNOVA $^{\mathrm{a}}$

\begin{tabular}{lllllll}
\hline Model & & Sum of Squares & Df & Mean Square & F & Sig. \\
\hline $\mathbf{1}$ & Regression & 55.168 & 1 & 55.168 & 100.193 & $.000^{\mathrm{b}}$ \\
& Residual & 109.023 & 198 & .551 & & \\
& Total & 164.191 & 199 & & & \\
\hline & & & & & \\
a. Dependent Variable: Int_Intensity & & & & \\
b. Predictors: (Constant), Ent_Orientation & & &
\end{tabular}

Table 11. Coefficients

\begin{tabular}{lcclll}
\hline Model & \multicolumn{2}{l}{ Unstandardized Coefficients } & Standardized Coefficients & & \\
& $\mathrm{B}$ & Standard Error & Beta & $\mathrm{T}$ & Sig. \\
\hline (Constant) & .883 & .283 & & 3.126 & .002 \\
Ent-Orientation & .751 & .075 & .580 & 10.010 & .000 \\
\hline
\end{tabular}

Note. Dependent Variable: Int_Intensity

Regression analyses of hypothesis two demonstrate that the model summary table is based on the predictors (Entrepreneurial orientation). So it is analyzed that $\mathrm{R}$ square has a value $\mathbf{0 . 3 3 6}$, which explains the $\mathbf{3 3 . 6 \%}$ variance in the relationship of Entrepreneurial orientation and internalization intensity. The second table ANOVA shows a F-value 100.193 which is significant at $\mathbf{0 0 0}$ because the significant value is less than 0.05 . And in the third table of coefficient, the standardized coefficient Beta value is $\mathbf{. 5 8 0}$. All the results show the significance level so Hypothesis one is proved.

Table 12. Model summary

\begin{tabular}{lllll}
\hline Model & $\mathbf{R}$ & R Square & Adjusted R Square & Std. Error of the Estimate \\
\hline $\mathbf{1}$ & $.543^{\mathrm{a}}$ & .295 & .291 & .76474 \\
\hline a. Predictors: (Constant), Network_Resources & & \\
\hline
\end{tabular}

Table 13. ANOVAa

\begin{tabular}{lllllll}
\hline Model & Sum of Squares & Df & Mean Square & F & Sig. \\
\hline $\mathbf{1}$ & Regression & 48.394 & 1 & 48.394 & 82.749 & $.000^{\mathrm{b}}$ \\
& Residual & 115.797 & 198 & .585 & & \\
\multicolumn{2}{l}{ Total } & 164.191 & 199 & & & \\
\hline a. Dependent Variable: Int_Intensity & & & & \\
b. Predictors: (Constant), Network_Resources & & & \\
\hline
\end{tabular}

Table 14. Coefficients ${ }^{\mathrm{a}}$

\begin{tabular}{lllllll}
\hline \multirow{2}{*}{ Model } & & \multicolumn{2}{c}{ Unstandardized Coefficients } & Standardized Coefficients & & \\
B & & B & Std. Error & Beta & T & Sig. \\
\hline $\mathbf{1}$ & (Constant) & .689 & .331 & & 2.080 & .039 \\
& Network_Resources & .829 & .091 & .543 & 9.097 & .000 \\
\hline a. Dependent Variable: Int_Intensity. & & & \\
\hline
\end{tabular}


Regression analysis of hypothesis two demonstrates that the model summary table is based on the predictors (Network resources). It is analyzed that $\mathrm{R}$ square has a value $\mathbf{0 . 2 9 5}$, which explains the $\mathbf{2 9 . 5 \%}$ variance in the relationship of network resources and internalization intensity. The second table Anova shows F-value 82.749 which is significant at $\mathbf{0 0 0}$ because the significant value is less than 0.05 . And in the third table of coefficient the standardized coefficient Beta value is $\mathbf{. 5 4 3}$. All the results show the significance level so Hypothesis two is proved.

\section{Conclusion}

According to the findings it has been proved that there is a significant impact of strong entrepreneurial support on internationalization intensity of SME's. It means that the SME's having experienced, flexible and skillful employees can progress quickly in international market. According to these results it has been proved that in Pakistan significant relationship exist between strong entrepreneurial orientation and internationalization intensity of SME's. SME's having strong local market due to skillful and experienced employees capture the international market very quickly. As it was investigated that for getting international market entrepreneurial orientation can be utilized in terms of pro-activeness and competitive aggressiveness as well as risk taking (Okpara, 2009).

The relationship between network resources utilization and internationalization intensity has also been proved significant in SME's of Pakistan. SME's having strong utilization of internal and external resources available capture the international market quickly through co-innovation by understanding and analysis of the changing needs and demands of the international market. SME's utilizing their network resources can compete with the local as well as international market as compared to the SME's not utilizing their network resources available. Co-innovation proves to be very important for progress in international market. It was investigated earlier that SME's need to utilize wider network resources for internationalization of their businesses (Jones et al., 2009).

\subsection{Research Implications}

This study is made to highlight the significance of strong entrepreneurial orientation for the development of SME's. This study aims to demonstrate that if SME's desire to enter the international market then the empowerment of entrepreneurial orientation in SME sector can support this purpose. The main purpose of this study is to prove the co-innovation as better strategy to get the competitive advantage and this can help in the development of SME sector not only on the local level but also at the international level.

The results of this study will prove to be very useful for the progress of the SME's which want to go in the international market and to make a prominent position in local as well as in international market.

\subsection{Limitations and Future Direction}

In this research impact of entrepreneurial orientation and utilization of network resources is studied on the internationalization intensity and performance of SME's. The first limitation of this research is that, this research can be done by using another dependent variable i-e globalization and find its impact on internationalization and performance of SME's. Second limitation of this study is that this paper has considered three dimensions of entrepreneurial orientation. Further research can be done by studying all five dimensions of entrepreneurial orientation. Third limitation of this research is that, this research has studied only manufacturing industry of SME's. This study can be done using other industries of SME's of Pakistan.

\section{Acknowledgement}

We would like to thank managers of SME's of Pakistan whose support make us possible to collect right data. Because of their collaboration and response our research is completed.

\section{References}

Abdulah, N. A. H., \& Zain, S. N. M. (2011). The Internationalization Theory and Malaysian Small Medium Enterprises (SMEs). International Journal of Trade, Economics and Finance, 2(4), 318-322. http://doi.org/10.7763/IJTEF.2011.V2.124

Adelegan, O. J., \& Ariyo, A. (2008). Capital market imperfections and corporate investment behavior: A switching regression approach using panel data for Nigerian manufacturing firms. Journal of Money, Investment and Banking, 2, 16-38. Retrieved from http://www.eurojournals.com/finance.htm

Ahmad, Y., Pirzada, M. D. S., \& Khan, M. T. (2013). Strategic Orientation of Small to Medium Scale Manufacturing Firms in Developing Country: A Case of Auto Parts Manufacturing Small to Medium Enterprises (SMEs) in Pakistan. Life Science Journal, 10(3), 517-527. Retrieved from https://www.researchgate.net/publication/289336173 
Aldrich, H. (1999). Organizations evolving. London: Sage Publications. Retrieved from http://journals.sagepub.com/doi/abs/10.1177/104225870102500404

Anderson, E. W., \& Sullivan, M. W. (1993). The antecedents and consequences of customer satisfaction for firms. Marketing Science, 12(2), 125-143. https://doi.org/10.1287/mksc.12.2.125

Autio, E., Sapienza, H. J., \& Almeida, J. G. (2000). Effects of age at entry, knowledge intensity, and imitability on international growth. Academy of Management Journal, 43(5), 909-924.

Bartlett, C. A., \& Ghoshal, S. (2000). Going global: lessons from late movers. Reading, 1(3). Retrieved from https://www.researchgate.net/profile/Christopher_Bartlett/publication/40963896

Begley, T. M., \& Boyd, D. P. (1987). Psychological characteristics associated with performence in entrepreneurial firms and smaller businesses. Journal of Business Venturing, 2(1), 79-93. https://doi.org/10.1016/0883-9026(87)90020-6

Bell, J. (1995). The internationalization of small computer software firms: A further challenge to "stage" theories. European Journal of Marketing, 29(8), 60-75. https://doi.org/10.1108/03090569510097556

Benjamin, S. M. (2005). Evaluating e-rulemaking: Public participation and political institutions. Duke LJ, 55, 893. Retrieved from http://ssrn.com/abstract=942055

Bjuggren, C. M., Johansson, D., \& Stenkula, M. (2012). Using self-employment as proxy for entrepreneurship: some empirical caveats. International Journal of Entrepreneurship and Small Business, 17(3), 290-303. https://doi.org/10.1504/IJESB.2012.049578

Brockhaus, R. H., \& Horwitz, P. S. (1986). The psychology of the entrepreneur. Entrepreneurship: Critical Perspectives on Business and Management, 2, 260-283.

Brown, J. D. (2011). Likert items and scales of measurement. Shiken: JALT Testing \& Evaluation SIG Newsletter, 15(1), 10-14. Retrieved from http://hosted.jalt.org/test/bro_34

Buckley, P. J., \& Ghauri, P. (1999). The Internationalization of the Firm: A Reader. London: International Thomson Business Press.

Calof, J. L., \& Beamish, P. W. (1995). Adapting to foreign markets: explaining internationalization. International Business Review, 4(2), 115-131. https://doi.org/10.1016/0969-5931(95)00001-G

Casillas, J. C., Moreno, A. M., Acedo, F. J., Gallego, M. A., \& Ramos, E. (2009). An integrative model of the role of knowledge in the internationalization process. Journal of World Business, 44(3), 311-322. https://doi.org/10.1016/j.jwb.2008.08.001

Cerrato, D., \& Piva, M. (2008). The Internationalization of Small and Medium-Sized Enterprises: The Effect of Family Management, Human Capital and Foreign Ownership. Joint Research Project Report, 1-25. Retrieved from https://link.springer.com/article/10.1007/s10997-010-9166-x

Clerq, D. D. E., Sapienza, H. J., \& Crijns, H. (2005). The Internationalization of Small and Medium-Sized Firms. Small Business Economics, 24, 409-419. https://doi.org/10.1007/s11187-005-5333-x

Coviello, N. E., Brodie, R. J., \& Munro, H. J. (2000). An investigation of marketing practice by firm size. Journal of Business Venturing, 15(5), 523-545. https://doi.org/10.1016/S0883-9026(98)00035-4

Covin, J. G., \& Slevin, D. P. (1990). New venture strategic posture, structure, and performance: an industry life

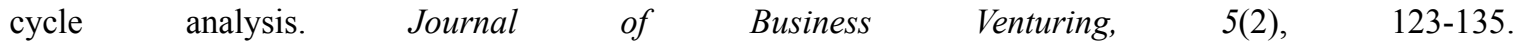
https://doi.org/10.1016/0883-9026(90)90004-D

Day, J., Dean, A. A., \& Reynolds, P. L. (1998). Relationship marketing: its key role in entrepreneurship. Long Range Planning, 31(6), 828-837. https://doi.org/10.1016/S0024-6301(98)80019-8

Dichtl, E., Leibold, M., Köglmayr, H. G., \& Mueller, S. (1984). The export-decision of small and medium-sized firms: A review. Management International Review, 49-60. Retrieved from http://www.jstor.org/stable/40227718

Ensari, M. Ş., \& Karabay, M. E. (2014). What Helps to Make SMEs Successful in Global Markets?. Procedia-Social and Behavioral Sciences, 150, 192-201. https://doi.org/10.1016/j.sbspro.2014.09.030

FBS. (2011). Economic Survey of Pakistan. Islamabad: Ministry of Finance, Government of Pakistan. https://doi.org/10.1016/S0140-6736(13)60019-7

Fletcher, D. (2004). International entrepreneurship and small business. Entrepreneurship Reg Dev, 16, 289-305. 
https://doi.org/10.1080/0898562042000263267

Ford, D., \& Mouzas, S. (2013). The theory and practice of business networking. Industrial Marketing Management, 42(3), 433-442. https://doi.org/10.1016/j.indmarman.2013.02.012

Fritsch, M. (2001). Co-operation in regional innovation systems. Regional Studies, 35(4), 297-307. https://doi.org/10.1080/00343400124434

Ginting, G. (2015). Open Innovation Model: Empowering Entrepreneurial Orientation and Utilizing Network Resources as Determinant for Internationalization Performance of Small Medium Agroindustry. Agriculture and Agricultural Science Procedia, 3, 56-61. https://doi.org/10.1016/j.aaspro.2015.01.013

Hussain, J., Ismail, K., \& Akhtar, C. S. (2015). Market Orientation and Organizational Performance: A Case of Pakistani SMEs. Social and Basic Sciences Research Review, 3(2), 125-136. Retrieved from https://www.researchgate.net/profile/Chaudhry_Akhtar/publication/271965104

Jasra, J. M., Khan, M. A., Hunjra, A. I., Rehman, R. A. U., \& Azam, R. I. (2011). Determinants of business success of small and medium enterprises. International Journal of Business and Social Science, 2(20), 274-280. Retrieved from https://papers.ssrn.com/sol3/papers.cfm?abstract_id=2130356

Javalgi, R. G., \& Ramsey, R. (2001). Strategic issues of e-commerce as an alternative global distribution system. International Marketing Review, 18, 376-391. https://doi.org/10.1108/02651330110398387

Javalgi, R. R. G., \& Todd, P. R. (2011). Entrepreneurial orientation, management commitment, and human capital: The internationalization of SMEs in India. Journal of Business Research, 64(9), 1004-1010. https://doi.org/10.1016/j.jbusres.2010.11.024

Johanson, J., \& Mattsson, L. G. (1988). Internationalisation in industrial systems-a network approach. In N. Hood \& J. E. Vahlne (Eds), Strategies in Global Competition, Croom Helm, London (pp. 287-314) Retrieved from https://link.springer.com/chapter/10.1057/9781137508829_5

Johanson, J., \& Vahlne, J. E. (2006). Commitment and opportunity development in the internationalization process: A note on the Uppsala internationalization process model. Management International Review, 46(2), 165-178. https://doi.org/10.1108/02651330110398387

Johanson, J., \& Wiedersheim, P. F. (1975). The internationalization of the firm-four Swedish cases. Journal of Management Studies, 12(3), 305-323. https://doi.org/10.1111/j.1467-6486.1975.tb00514.x

Jones, M. V., Dimitratos, P., Fletcher, M., \& Young, S. (2009) Internationalization, Entrepreneurship and the Smaller Firm: Evidence from Around the World. USA: Edward Elgar. https://doi.org/10.4337/9781848447363

Kam Sing Wong, S. (2012). The influences of entrepreneurial orientation on product advantage and new product success. Journal of Chinese Entrepreneurship, 4(3), 243-262. https://doi.org/10.4337/9781848447363

Karagozoglou, N., \& Lindell, M. (1998). Internationalization and small and medium sized technology-based firms: an exploratory study. Journal of Small Business Management, 36(1), 44-59. https://doi.org/10.1509/jsbm.8.3.10.19635

Kiss, A. N., Danis, W. M., \& Cavusgil, S. T. (2012). International entrepreneurship research in emerging economies: A critical review and research agenda. Journal of Business Venturing, 27(2), 266-290. https://doi.org/10.1016/j.jbusvent.2011.09.004

Knight, G. (2001). Entrepreneurship and strategy in the international SME. Journal of International Management, 7, 155-71. https://doi.org/10.1016/S1075-4253(01)00042-4

Lan, Q., \& Wu, S. (2010). An Empirical Study of Entrepreneurial Orientation and Degree of Internationalization of Small and Medium Sized Chinese Manufacturing Enterprises. Journal of Chines Entrepreneurship, 2(1) 53-75. https://doi.org/10.1108/17561391011019023

Lieberman, M. B., \& Montgomery, D. B. (1988). First-mover advantages. Strategic Management Journal, 9(S1), 41-58. https://doi.org/10.1002/smj.4250090706

Lumpkin, G. T., \& Dess, G. G. (1996). Clarifying the entrepreneurial orientation construct and liking it to performance. Academy of Management Review, 21(1), 135-172.

MacMillan, I. C., \& Day, D. L. (1987). Corporate ventures into industrial markets: Dynamics of aggressive entry. Journal of Business Venturing, 2(1), 29-39. https://doi.org/10.1016/0883-9026(87)90017-6

Masum, M., \& Fernandez, A. (2008). Internationalization Process of SMEs: Strategies and Methods. OAI: 
oai:DiVA.org:mdh-859.

McDougall, P. P., \& Oviatt, B. M. (2000). International entrepreneurship: the intersection of two research paths. Academy of Management Journal, 43(5), 902-906. https://doi.org/10.2307/1556418

McMullen, J. S., \& Shepherd, D. A. (2006). Entrepreneurial action and the role of uncertainty in the theory of the entrepreneur. Academy of Management Review, 132-152. https://doi.org/10.5465/AMR.2006.19379628

Melia, M. R., Boulard, M. M., \& Peinado, L. S. (2007). Entreprenurial Orientation and International Commitment. Journal of International Entrepreneurship, 5, 65-83. https://doi.org/10.1007/s10843-007-0016-0

Miller, A., \& Camp, B. (1986). Exploring determinants of success in corporate ventures. Journal of Business Venturing, 1(1), 87-105. https://doi.org/10.1016/0883-9026(85)90009-6

Miller, D. (1983). The correlates of entrepreneurship in three types of firms. Management Science, 29(7), $770-791$. https://doi.org/10.1287/mnsc.29.7.770

Miller, D., \& Friesen, P. H. (1978). Archetypes of strategy formulation. Management Science, 24(9), 921-933. https://doi.org/10.1287/mnsc.24.9.921

Mirani, M. A., \& Shah, S. M. M. (2012). What does it take to succeed in small business in Pakistan? The Lessons for Emerging Entrepreneurs. International Journal of Trade, Economics and Finance, 3, 167-169. https://doi.org/10.7763/IJTEF.2012.V3.193

Mustafa, I., \& Khan, F. M. (2005). Small and medium enterprises in Pakistan. South Asian Journal, 9(3), 1-16. Retrieved from https://papers.ssrn.com/sol3/papers.cfm?abstract_id=2225361

Norman, G. (2010). Likert scales, levels of measurement and the "laws" of statistics. Advances in Health Sciences Education, 15(5), 625-632. https://doi.org/10.1007/s10459-010-9222-y

Odenthal, S., Tovstiga, G., Tambe, G., \& Van Oene, F. (2004). Co-Innovation; Capturing the Innovation Premium for Growth. Arthur D. Little. Prism. Retrieved from http://centaur.reading.ac.uk/23134/

Okpara, J. O. (2009). Strategic Choices, Export Orientation and Export Performance of SMEs in Nigeria. Journal Management Decision, 47(8), 1281-1299. https://doi.org/10.1108/00251740910984541

Oviatt, B. M., \& McDougall, P. P. (1994). Towarda theoryof international new ventures. Journal of International Business Studies, 25(1), 45-64. https://doi.org/10.1057/palgrave.jibs.8490193

Porter, M. E., \& Millar, V. E. (1985). How information gives you competitive advantage. Retrieved from https://hbr.org/1985/07

Realp, M., Pérez-Neira, A. I., \& Mecklenbrauker, C. (2005, May). A cross-layer approach to multi-user diversity in heterogeneous wireless systems. In Communications, 2005. ICC 2005. 2005 IEEE International Conference on (Vol. 4, pp. 2791-2796). IEEE. https://doi.org/10.1109/ICC.2005.1494858

Rosson, P. J., \& Reid, S. D. (1987). Managing export entry and expansion: concepts and practice. Praeger. Retrieved from http://agris.fao.org/agris-search/search.do?recordID=US9020038

Schweizer, R., Vahlne, J. E., \& Johanson, J. (2010). Internationalization as an entrepreneurial process. Journal of International Entrepreneurship, 8(4), 343-370. https://doi.org/10.1007/s10843-010-0064-8

Shane, S. (1994). Cultural values and the championing process. Entrepreneurship: Theory and Practice, 18(4), 25-42. https://doi.org/10.1177/104225879401800402

Snehota, I., \& Hakansson, H. (Eds.). (1995). Developing relationships in business networks. London: Routledge.

Stinchcombe, A. L., \& March, J. G. (1965). Social structure and organizations. Handbook of Organizations, 7, 142-193.

Sullivan, D. (1994). Measuring the degree of internationalization of a firm. Journal of International Business Studies, 25(2), 325-342. https://doi.org/10.1057/palgrave.jibs.8490203

Venkatraman, N. (1989). Strategic orientation of business enterprises: The construct, dimensionality, and measurement. Management Science, 35(8), 942-962. https://doi.org/10.1287/mnsc.35.8.942

Verdin, P., \& Heck, N. V. (2001). From Local Champions to Global Masters: A strategic Perspectives on Managing Internationalization. New York: Palgrave. https://doi.org/10.1057/9780230514324

Wacker, J. G., \& Sprague, L. G. (1998). Forecasting accuracy: comparing the relative effectiveness of practices between seven developed countries. Journal of Operations Management, 16(2), 271-290. 
https://doi.org/10.1016/S0272-6963(97)00042-9

Webster Jr, F. E. (1992). The changing role of marketing in the corporation. The Journal of Marketing, 1-17. https://doi.org/10.2307/1251983

Welch, L. S., \& Luostarinen, R. (1988). Internationalization: Evolution of a concept. Journal of General Management, 14(2), 34-55. https://doi.org/10.1177/030630708801400203

Yener, M., Doğruoğlu, B., \& Ergun, S. (2014). Challenges of Internationalization for SMEs and Overcoming these Challenges: A case study from Turkey. Procedia-Social and Behavioral Sciences, 150, 2-11. https://doi.org/10.1016/j.sbspro.2014.09.002

Zahra, S. A., \& Garvis, D. (2000). International corporate entrepreneurship and firm performance: the moderating effect of international environmental hostility. Journal of Business Venturing, 15, 469-492. https://doi.org/10.1016/S0883-9026(99)00036-1

\section{Copyrights}

Copyright for this article is retained by the author, with first publication rights granted to the journal.

This is an open-access article distributed under the terms and conditions of the Creative Commons Attribution license (http://creativecommons.org/licenses/by/4.0/). 